\title{
High and New Technology Enterprise Performance and Financial Constraints: Is Clustering Efficient?
}

\author{
Qianfei Shu $^{1}$, Go Yano ${ }^{1}$ \\ ${ }^{1}$ Graduate School of Economics, Kyoto University, Kyoto, 606-8501, Japan \\ Correspondence: Qianfei Shu, PhD candidate, Graduate School of Economics, Kyoto University, Kyoto, 606-8501, \\ Japan.
}

Received: October 1, 2017

doi:10.11114/aef.v4i6.2678
Accepted: October 27, $2017 \quad$ Available online: October 29, 2017

URL: https://doi.org/10.11114/aef.v4i6.2678

\begin{abstract}
Using firm level panel data for non-listed high and new technology enterprises in the Yangtze River Delta of China from 2002-2009, we investigated the importance of the high and new technology industrial development zone (HNTIDZ) established by the Chinese government for improving enterprise performance. We found that high and new technology enterprises located in HNTIDZs enjoy superior productivity, growth potential, export and innovation activity; better access to trade credit and bank loan facilities plays a significant role in promoting productivity, growth and export, but it does not affect innovation activity; in national HNTIDZs, enterprises that are more in need of trade credit and bank loan have better performance in the respect of productivity, growth, export as well as innovation activity.
\end{abstract}

Keywords: cluster, trade credit, bank loan, enterprise performance, industrial development zone

\section{Introduction}

This research focused on high and new technology (HNT) industries in China, and investigated the effect of high and new technology industrial clusters established by the Chinese government at the end of 1980s. The first question is whether the presence of HNT industrial clusters contributes to enterprise performance, and the second question is whether financial system efficiency influences enterprise performance through HNT industrial clusters.

From 2002-2011, the average proportion of HNT enterprises compared to the total number of manufacturing industry enterprises in China was only $6.8 \%$ (Figure 1). However, gross HNT industrial output accounted for $14.3 \%$ of the main economic indicators for the manufacturing industry. (Figure 2), and played a significant role in national industrialization. (Note 1)

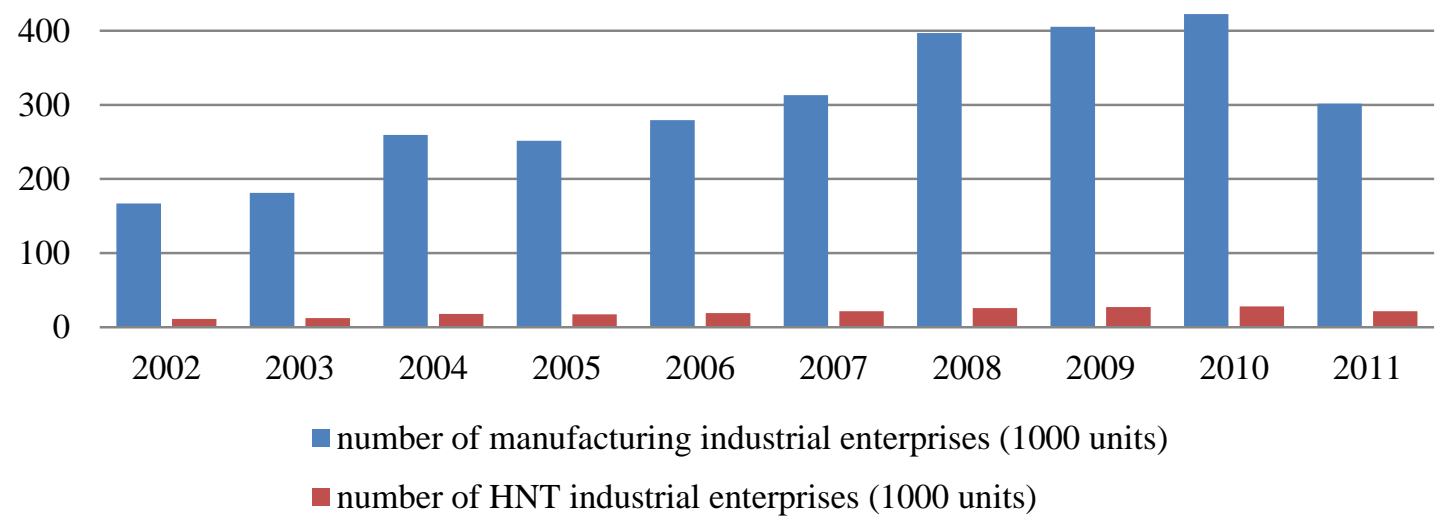

Figure 1. Manufacturing HNT§ industrial enterprises

§high and new technology 


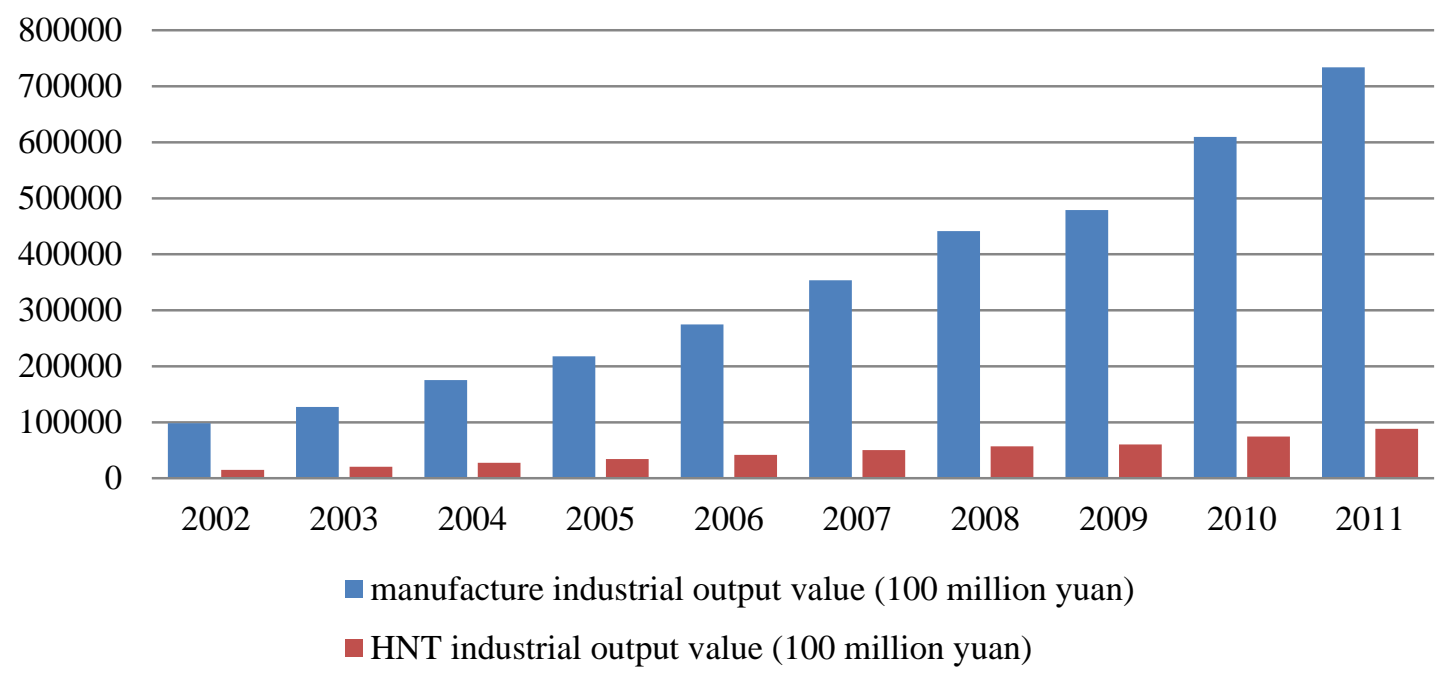

Figure2. Manufacturing and HNT§ industry output

§high and new technology

The HNT industry in China can be characterized as follows.

1. Knowledge, technology, and research and development (R\&D) capital intensive. Global development of HNT industry has seen equipment and machines replaced by intangible factors, such as information, technology, and patents, which have a larger impact on enterprise performance.

2. High innovation and high risk. The high innovation level of HNT industry determines the characteristics of high risk. First, large and continuous acquisition of talent and financial resources are essential to support technical innovation, which is costly for HNT enterprises. However, it is impossible to achieve economic benefit in the event when technical innovation is unsuccessful.

3. High earning capacity and return on investment. Once the high technology products win market recognition, HNT enterprise accomplish capital accumulation in a short time.

Thus, compared with other enterprises, HNT enterprises require a well-developed financial system to satisfy many funding demands to support enterprise performance growth. Many studies have shown that an excellent financial system can promote industrial development by improving enterprise performance (Fazzari et al., 1988; King \& Levine, 1993; Nickell \& Nicolitsas, 1999; Rajan \& Zingales, 1998; Hall, 2002; Wurgler, 2000).

HNT industry in China is still in its infancy, beset by many difficulties, including difficult financing. Banks tend to refuse loans for HNT industrial enterprises because of their high risk and uncertainty. However, in spite of the less developed financial system, gross industrial output of HNT industry increased 490\% at current prices over the past ten years. (Note 2) Indeed, the reason for China's explosive growth over the past three decades, not only the HNT industry, without an adequate financial system remains a puzzle. At firm level, Allen et al. (2005) suggested that although financial institutions are poorly developed in China, informal finance plays a tremendous role, providing funds by means of loans from family and friends. Another common non-standard financing channel is trade credit, which has helped China's private enterprises overcome funding deficiencies and achieve rapid growth. Many scholars have shown that trade credit provides a significant alternative financing channel in China. Fisman and Love (2003) showed that enterprises tended to rely on trade credit as a funding resource, supporting enterprise growth. Ge and Qiu (2007) showed that informal finance of trade credit was utilized more by non-state owned enterprises to foster growth when formal finance was less developed. Lin and Sun (2005) argued that China's informal finance sectors substituted for formal finance to some extent in the growth of SMEs. Cull et al. (2009) showed that fruitful private sectors were inclined to provide trade credit as substitute finance for customers. In contrast, Du et al. (2012) showed that access to bank loans was central to promoting enterprise growth, with the availability of trade credit being much less effective.

Therefore, for Chinese HNT enterprises, do trade credit and bank loans actually provide two effective financing resources for improving enterprise performance? If so, which is more efficient? If not, how do enterprises overcome financial constraints? This study explores some answers from an industrial clustering point of view. Dating back to the 1980s, to stimulate development of HNT industries, the Chinese government provided the torch plan project, with the key policy focus of setting up HNT industrial development zones (HNTIDZs). The government defined specific areas and formulated a series of preferential policies (e.g. income tax reduction, export and import tariff exemption), to 
encourage HNT industrial enterprises to enter the zone. Since the establishment of first HNTIDZ, Zhongguancun Science and Technology Park in Beijing, by the end of 2014, 113 national and hundreds of provincial HNTIDZs have been established in China. In this paper, we treat HNTIDZ as the industrial cluster.

Many previous studies have focused on how industrial cluster or financing sectors affect enterprise performance, such as productivity, innovative activity and export. However, few have explored how financing sectors influence enterprise performance through the presence of an artificial industrial cluster, i.e., HNTIDZs, for new technology based enterprises. This paper explores this question, based on the Yangtze River Delta, which includes Jiangsu Province, Zhejiang Province and Shanghai Municipality, and investigate the efficiency of trade credit and bank loans in stimulating enterprise performance through HNTIDZ, using a panel of 909 enterprises over 2002-2009. The Yangtze River Delta is the most developed region in China. By 2014, the Yangtze River Delta had 21.9\% of the total HNTIDZs in China. (Note 4) A suitable financial system is critical for growth of HNT enterprises. If HNTIDZs have a driving effect between financial system and enterprise performance, they could be a development model for HNT industry in China.

To our knowledge, this study is the first to use firm level data to investigate whether the financing system can boost enterprise performance in the HNT industrial field. Our second contribution is that we particularly consider the contribution of capital intensive industrial clusters formed by external forces on enterprise activities.

The remainder of this paper is organized as follows. Section 2 provides literature review regarding industrial cluster, and its impact on enterprise performance. Section 3 describes the study data and Section 4 explains the empirical models employed. Section 5 reports estimation results and comparisons, and Section 6 presents our conclusions.

\section{Literature Review}

The first related research area is industrial cluster. An HNTIDZ in essence is an industrial cluster, and only differs from a traditional industrial cluster in that the former is government planned whereas the latter is self-organized by markets force. Following Porter (1990), a cluster is defined as geographic concentrations of interconnected companies and institutions in a particular business field. Furthermore, from the point of view of clustering and industrialization, Schmitz and Nadvi (1999) defined clusters as sectoral and spatial concentrations of firms.

The first factor for formation of an industrial cluster is spatial agglomeration of industries. An HNTIDZ is a physical region designated by the Chinese government to attract a large number of enterprises by offering financial incentives through a set of preferential policies. This provides the spatial feasibility for formation of an industrial cluster and opportunity to maximize its advantages. The second characteristic of an industrial cluster is inter-connected companies. As indicated in Porter's more detailed description, these companies include, for example, suppliers of specialized inputs such as components, machinery, and services as well as providers of specialized infrastructure. Clusters also often extend downstream to channels or customers and laterally to manufacturers of complementary products or companies related by skills, technologies or common inputs (Porter, 2000, p16-17). Within the same cluster, it is more likely for enterprises to utilize homogeneous inputs and share information, skill, as well as technologies if they manufacture similar products.

Thus, an industrial cluster emphasizes both spatially and operationally the connection among enterprises, which relies on endogenous forces. Although HNTIDZ is a government led growth model, the intention is to bring HNT enterprises together in a specific area and strengthen enterprise ties in the aspects of intelligence, skill, technology, capital, talent, etc. Because an HNTIDZ is designated for a specific classification of industry (Note 3), it is highly likely that enterprise within the zone will use similar inputs for production, share skills and technologies, and possess identical suppliers and customers, hence forming important interconnections among enterprises and increase productivity in the zone (Combes et al., 2011). Moreover, an industrial development zone contributes to building trustworthy relationships and cooperation among enterprises. All of these factors have positive impact on formation of valid industrial clusters for the government led industrial development zones. Therefore, the effects of HNTIDZs and industrial clusters are similar, although the former is an external force based growth model.

In addition, industrial clusters are notable in developing and developed countries (Marshall, 1920; Piore and Sabel, 1984; Klugman, 1991; Porter, 1998). Schmitz and Nadvi (1999) argue that clustering provides newly established small enterprises with assistance for avoiding initial business ventures. Clustering also helps medium and large enterprises to cope with global competitive pressures. Sonobe and Otsuka (2006) discussed comparative case studies of merchant led, engineer led, machine tool, and printed circuit board industrial clusters located in Japan, China, and Taiwan. They found that taking advantage of human capital in clusters could be an effective strategy for industrial development. Glaeser and Gottlieb (2009) focused on the effects of clustering in modern cities to accelerate the flow of ideas, rather than decreasing the costs of moving goods. Ruan and Zhang (2009) described a cashmere sweater cluster in China, and found that clustering lowered the entry barrier for entrepreneurs by dividing a unified production process into many piece meal steps. Long and Zhang (2011) indicated that industrial clusters enable enterprises to achieve higher levels of 
exports and total factor productivity. Colombo and Delmastro (2002) suggested that HNTIDZs play an important role in facilitating growth, innovative activity and advanced scientific technologies of new technology oriented enterprises in Italy. In the case of China, Cao (2004) showed that enterprises within high technology parks could utilize clustering advantages to achieve higher levels of innovation. Hu (2007) found that HNTIDZs contribute to revitalizing regional economic growth.

\section{Data and Descriptive Statistics}

Most data used in this paper are drawn from the China Non-listed Enterprise Database (GTA) for 2002-2009. The data was first cleaned using the following procedures.

- As discussed in endnote 3, the range of industries for this study was limited to include manufacture of medical equipment, measuring instruments, medicines, aircraft and spacecraft, and communication equipment.

- We select enterprises located in the Yangtze River Delta region in southeast China, including Jiangsu and Zhejiang provinces and Shanghai municipality.

- Enterprises with less than three successive year data were excluded since we use a two-step system GMM. (Note 5)

- We distinguish enterprises situated in HNTIDZs.

Thus, 909 enterprises with 6030 firm-year observations comprised the unbalanced panel.

Table 1 summarizes the selected variables for the whole enterprise panel. According to the address of enterprises, the proportion of enterprises within national HNTIDZs (cluster1) was $20.4 \%$, whereas the ratio of enterprises within provincial HNTIDZs (cluster2) was 31.4\%. Therefore, over 50\% of firm-year observations were enterprises located in HNTIDZs.

Table 1. Descriptive Statistics ${ }^{\S}$

\begin{tabular}{|c|c|c|c|}
\hline Variables & Mean & $\begin{array}{c}\text { Standard } \\
\text { Deviation }\end{array}$ & Observations \\
\hline \multicolumn{4}{|l|}{ Dependent Variables } \\
\hline $\ln ($ value added) & 9.847 & 1.894 & 6030 \\
\hline Growth Rate of Sales & 0.186 & 0.713 & 6030 \\
\hline Delivery Value of Export/ Total Assets & 0.535 & 0.971 & 6030 \\
\hline Output value of New Product/ Total Assets & 0.122 & 0.498 & 6030 \\
\hline \multicolumn{4}{|l|}{$\begin{array}{l}\text { Independent Variables } \\
\text { (1) Cluster dummy }\end{array}$} \\
\hline Cluster1 & 0.204 & 0.403 & 6030 \\
\hline $\begin{array}{l}\text { Cluster2 } \\
\text { (2) Financial Variable }\end{array}$ & 0.314 & 0.464 & 6030 \\
\hline Net trade credit/ Total Assets $\mathrm{t}_{\mathrm{t}-1}$ & -0.040 & 0.243 & 6030 \\
\hline Bank Loan/ Total Assets $\mathrm{t}_{\mathrm{t} 1}$ & 0.338 & 0.336 & 6030 \\
\hline Cluster $1 *$ Net trade credit $_{\mathrm{t}-1}$ & 0.003 & 0.129 & 6030 \\
\hline Cluster $2 *$ Net trade credit & -0.019 & 0.120 & 6030 \\
\hline Cluster $1 *$ Bank loan $_{\mathrm{t}-1}$ & 0.049 & 0.138 & 6030 \\
\hline $\begin{array}{l}\text { Cluster } 2 * \text { Bank loan } \\
\text { (3) Control Variables }\end{array}$ & 0.111 & 0.206 & 6030 \\
\hline $\operatorname{Ln}(\text { fixed assets })_{\mathrm{t}-1}$ & 9.389 & 1.921 & 6030 \\
\hline $\mathrm{Ln}(\text { labor })_{\mathrm{t}-1}$ & 5.387 & 1.250 & 6030 \\
\hline Liquidity $_{\mathrm{t}-1}$ & 0.656 & 0.199 & 6030 \\
\hline Age & 11.456 & 9.499 & 6030 \\
\hline Sales/Total Asset ${ }_{\mathrm{t}-1}$ & 1.391 & 1.244 & 6030 \\
\hline Foreign Share & 0.264 & 0.415 & 6030 \\
\hline HMT Share & 0.146 & 0.328 & 6030 \\
\hline Private Share & 0.348 & 0.452 & 6030 \\
\hline
\end{tabular}

${ }^{\S}$ The table summarizes the selected variables for the whole enterprise panel.

\section{Empirical Model}

\subsection{Baseline Model}

To investigate the contributions of HNTIDZs, trade credit, and bank loans, to enterprise performance, the following two empirical models were used, 


$$
y_{1, i t}=\alpha_{0}+\alpha_{1} c l u_{1, i}+\alpha_{2} c l u_{2, i}+\alpha_{3} T C_{i t-1}+\alpha_{4} B L_{i t-1}+\gamma_{1} X_{i t-1}+\mu_{\mathrm{i}}+\mu_{\mathrm{j}}+\mu_{\mathrm{t}}+\mu_{\mathrm{c}}+\varepsilon_{\mathrm{it}}
$$

and

$$
y_{2, i t}=\alpha_{0}+\alpha_{5} c l u_{1, i}+\alpha_{6} c l u_{2, i}+\alpha_{7} T C_{i t-1}+\alpha_{8} B L_{i t-1}+\gamma_{2} X_{i t-1}+\mu_{\mathrm{i}}+\mu_{\mathrm{j}}+\mu_{\mathrm{t}}+\mu_{\mathrm{c}}+\varepsilon_{\mathrm{it}},
$$

where $\mathrm{i}$ and $\mathrm{t}$ indicate the enterprise and time, respectively. $\mathrm{y}_{1, \text { it }}$ denotes an enterprise's productivity and growth performance. The former was measured by the logarithm of value added, which has been widely used in previous studies as a significant variable to capture an enterprise's economic production and competitive performance (Singh et al. 2000; Lin et al., 2011; Zhang and Sonobe, 2011; Long and Zhang, 2011). We used the enterprise's sales growth rate, measured by the ratio of $\Delta$ sales to sales $t_{t-1}$ (Note 6), to represent growth performance. $y_{2, \text { it }}$ denotes an enterprise's export and innovation capability. Export was measured by export delivery value, while new product output value was used for innovation ability (Nam et al., 2008; Zhang, 2015). These were normalized by the size of total assets.

Two types of cluster dummies, $\mathrm{Clu}_{1}$ and $\mathrm{clu}_{2}$, were used to identify if the enterprise was located in a national or provincial HNTIDZ, where $\operatorname{clu}_{1, \mathrm{i}}=1$ if the enterprise is situated in a national HNTIDZ and zero otherwise, and $\operatorname{clu}_{2, \mathrm{i}}$ $=1$ if the enterprise is situated in a provincial HNTIDZ and zero otherwise. Both are time invariant variables, so the suffix is i, not it. The influence of HNTIDZ on enterprise performance can be analyzed using the cluster dummies.

$\mathrm{TC}_{\mathrm{it}-1}$ indicates net trade credit as the informal financing source, measured by accounts payable - accounts receivable. Accounts payable means trade credit supplied by business partners, while accounts receivable represents the extension of trade credit to customer enterprises. Following Ge and Qiu (2007), this term is treated as a balanced result of the use of trade credit, because enterprises receive and extend trade credit simultaneously. $\mathrm{BL}_{\mathrm{it}-1}$ denotes bank loans as the normal financing source from bank. We use short term loans to represent bank loans. Both net trade credit and bank loans are normalized by the size of total assets.

A set of control variables, $X_{i t-1}$, including $\ln (\text { fixed asset })_{i, t-1}, \ln (\text { labor })_{i, t-1}$, enterprise age and size dummies, foreign owned share, private owned share, liquidity $y_{\mathrm{i}, \mathrm{t}-1}$, net profit $\mathrm{i}_{\mathrm{i}, \mathrm{t}-1}, \ln \left(\right.$ fixed asset $_{\mathrm{i}, \mathrm{t}-1}$, and $\ln (\text { labor })_{\mathrm{i}, \mathrm{t}-1}$ represent an enterprise's fixed assets and number of employees, based on Cobb-Douglas production function when the dependent variable is $\ln$ (value added). (Note 7) Enterprise age was measured by the difference between the year of establishment and the sample year, while enterprise size dummies for large or small and medium sized enterprises (SMEs) (Note 8) were also included.

Enterprise age and size have been analyzed previously for their effect on enterprise performance (Cabral, 1995; Majumda, 1997; Biesebroeck, 2005; Palangkaraya et al., 2009). Foreign owned share is the percentage ratio of total shares held by foreign, Hong Kong, Marco, and Taiwan investors. Similarly, private owned share is the ratio of total shares held by individual investors. Finally, liquidity ${ }_{i, t-1}$, net profit $_{i, t-1}$, and sales $_{i, t-1}$ are current capital, cash flow, and managerial situation which are also normalized by the enterprise total assets. All independent variables are one-period lagged except enterprise cluster dummies, enterprise age, and size to avoid reverse causality in the model.

The disturbance term has four components: $\mu_{\mathrm{i}}$ is the firm specific fixed effect, and $\mu_{\mathrm{j}}$ is the industry specific effect that we control for by including HNT industry dummies. Representations of time and city specific effect dummies are also included in the empirical model, denoted by $\mu_{\mathrm{t}}$ and $\mu_{\mathrm{c}}$, respectively. $\varepsilon_{\text {it }}$ is an idiosyncratic error term; and $\alpha_{1}$, $\alpha_{2}, \alpha_{3}, \alpha_{4}, \alpha_{5}, \alpha_{6}, \alpha_{7}, \alpha_{8}, \gamma_{1}$, and $\gamma_{2}$ are coefficients to be estimated.

\subsection{Further Investigation}

To analyze the role played by HNTIDZ on enterprise activity when presented with trade credit and bank loan, we conducted the following augmented empirical models:

$$
\begin{aligned}
& y_{1, i t}=\alpha_{0}+\alpha_{9} c l u_{1, i}+\alpha_{10} c l u_{2, i}+\alpha_{11} T C_{i t-1}+\alpha_{12} \operatorname{clu}_{1, i} \times T C_{i t-1}+\alpha_{13} \operatorname{clu}_{2, i} \times T C_{i t-1}+\alpha_{14} B L_{i t-1}+\alpha_{15} \operatorname{clu}_{1, i} \times \\
& B L_{i t-1}+\alpha_{16} \operatorname{clu}_{2, i} \times B L_{i t-1}+\gamma_{3} X_{i t-1}+\mu_{\mathrm{i}}+\mu_{\mathrm{j}}+\mu_{\mathrm{t}}+\mu_{\mathrm{c}}+\varepsilon_{\mathrm{it}}
\end{aligned}
$$

and

$$
\begin{aligned}
& y_{2, i t}=\alpha_{0}+\alpha_{17} \operatorname{clu}_{1, i}+\alpha_{18} \operatorname{clu}_{2, i}+\alpha_{19} T C_{i t-1}+\alpha_{20} \operatorname{clu}_{1, i} \times T C_{i t-1}+\alpha_{21} \operatorname{clu}_{2, i} \times T C_{i t-1}+\alpha_{22} B L_{i t-1}+\alpha_{23} \operatorname{clu}_{1, i} \times \\
& B L_{i t-1}+\alpha_{24} \operatorname{clu}_{2, i} \times B L_{i t-1}+\gamma_{4} X_{i t-1}+\mu_{\mathrm{i}}+\mu_{\mathrm{j}}+\mu_{\mathrm{t}}+\mu_{\mathrm{c}}+\varepsilon_{\mathrm{it}}
\end{aligned}
$$

We pay particular attention to the interacting terms: clu $\times \mathrm{TC}_{\mathrm{it}-1}$ and clu $\times \mathrm{BL}_{\mathrm{it}-1}$, which are involved in the augmented empirical models. $\alpha_{12}, \alpha_{13}, \alpha_{15}, \alpha_{16}, \alpha_{20}, \alpha_{21}, \alpha_{23}$,and $\alpha_{24}$ capture the divergence between enterprises within and outside HNTIDZs with regard to the impact of trade credit and bank loan on enterprise performance. If 
enterprises within HNTIDZs achieve superior performance due to more effective application of finance, $\alpha_{12}, \alpha_{13}$, $\alpha_{15}, \alpha_{16}, \alpha_{20}, \alpha_{21}, \alpha_{23}$, and $\alpha_{24}$ should be positive. More precisely, because we divide the cluster dummy into two types, as explained in Section 4.1, there will be four interaction terms in (3) and (4) respectively. The other variables stay the same as described above.

\subsection{Estimation Methodology}

The system generalized method of moments (GMM) estimator designed by Arellano and Bond (1991) and Blundell and Bond (1998) was used when estimating (1) and (3). The merit of system GMM estimator is the treatment of possible endogeneity problems from independent variables in estimations and weak instrument problems in the first differenced GMM.

In the proposed model, except for cluster, enterprise age, industry, city, and year dummies, all independent variables are one period lagged, to avoid endogeneity. However, these are predetermined variables may be correlated with the lagged idiosyncratic error term, $\varepsilon_{\text {it }}$. Therefore, we use two or more period lagged endogenous variables as instrumental variables in (1) and (3), while cluster, age, industry, city, and year dummies are treated as exogenous variables.

Another key point of system GMM is the validity of instrumental variables. First, as the overidentifying restriction test, the Hansen test was conducted to confirm instrument exogeneity, but the Sargan test was not adopted because it is not robust to heteroscedasticity. Second, the pure error term $\varepsilon_{\text {it }}$ is required to be serially uncorrelated. Following Arellano and Bond (1991), first order serial correlation of the error term is permitted in difference regression. However, if second order serial correlation exists for the error term, the null hypothesis autoregressive (AR) test will be rejected. Tables 2 and 5 show that all AR (2) $>0.1$, which indicates that the instruments used are valid in our models.

Since only approximately $50 \%$ of all enterprises are export business and only approximately $16 \%$ of those have new production output, a large number of dependent variables are left-censored to zero. Therefore, to avoid biased regression results, (2) and (4) are estimated using the random effects Tobit model, (Note 9) so the export and new product output variable is

$$
y_{2, i t}=\left\{\begin{array}{ll}
y_{2, i t}^{*}, & \text { if } y_{2, i t}>0 \\
0, & \text { if } y_{2, i t} \leq 0
\end{array},\right.
$$

where $\mathrm{y}_{2, \text { it }}$ denotes the export and new product output as described in Section 4.1.

\section{Estimation Results and Discussion}

Table 2 shows estimations for (1), where columns 1-3 use $\ln$ (value added) as the dependent variable, and columns 4-6 use sales growth rate. The Hansen test of overidentifying restrictions cannot be rejected at the five percent level, showing that all the instrumental variables are exogenous for any specification. Furthermore, serial correlation of $\varepsilon_{\text {it }}$ is not found for any specification through AR (2) tests. Thus, instrumental variables used for estimation are valid (Roodman, 2009).

\subsection{HNTIDZ and Financial Effect on Enterprise Economic Performance}

The first question we focus on is: Do HNTIDZs improve firm level productivity and growth? Table 2 shows basic results obtained from (1). Columns 1-6 show that the coefficients of cluster1 dummies are positive and statistically significant, indicating that enterprises located in national HNTIDZs are more likely to exhibit better performance in respect of productivity and growth potentiality. This implies that national HNTIDZs contribute to fostering competition among enterprises and reducing production and transaction costs of intermediate inputs, thereby increasing enterprise productivity and sales growth. The significantly positive association between another cluster dummy, cluster 2 , and sales growth rate in columns 4-6 implies there is a tremendous opportunity for further development of enterprises within provincial HNTIDZs. However, columns $1-3$ show that cluster2 is positively but almost not significantly correlated with $\ln$ (value added), which means that enterprises within provincial HNTIDZs do not enjoy as much productivity advantage as sales growth.

We examined the influence of financing through trade credit or bank loan on firm performance in all specifications. According to Table 2, the significantly positive coefficients estimated for net trade credit in all specifications demonstrate that increasing the net value of receiving trade credit from business partners leads to better performances in the form of higher value added and sales growth. This is consistent with Allen et al. (2005), Cull (2009), Ge and Qiu (2007), and Yano and Shiraishi (2012), who also show that trade credit works as an alternative external financing source, and plays a pivotal role in promoting enterprise productivity and growth. Bank loans are also positively significantly correlated with value added and sales growth rate in almost all columns, implying that enterprises with more access to bank loan have a higher level of enterprise performance. 
This confirms that bank loan contributes to enhancing firm level productivity and enterprise growth as the formal financing source, which is also consistent with previous research (e.g. Ayyagari, et al., 2010; and Du et al., 2012). These findings correspond with our expectations, regardless bank loan or trade credit, external financial contributes to generating superior enterprise performance. This is probably because more flexible application of capital helps HNT enterprises perform professionally, such as training of senior technical staff, equipment and patent purchases, as well as investment in R\&D, etc. The inputs are all meaningful for HNT industry and hence stimulate enterprise productivity and growth potential.

Regarding the influence of enterprise characteristics, we observe that both the number of employees and the net value of fixed assets are positively and significantly associated with the enterprise value added, as expected. Furthermore, the large enterprise dummies exert positive and statistically significant effect on $\ln$ (value added), while the coefficients for SME dummy are negative and statistically significant. This means that larger scale enterprises are more likely to achieve efficient productivity, which is consistent with previous findings for Chinese industries from Bai et al. (2004) and Hu et al. (2015).

The negative relationship between enterprise age and sales growth rate can be interpreted as younger enterprises, particularly younger HNT enterprises, may have greater growth potential. This is probably because young enterprises have advantages in intangible competitiveness, such as production innovation, advanced technologies, and talent cultivation, which are important factors for HNT industry to stimulate enterprise performance growth. This is consistent with some previous studies, e.g. Lin et al. (2011) and Hu et al. (2015). Net profit also has significance in estimates for enterprise productivity, implying that improved cash flow may promote enterprise productivity.

Table 2. HNTIDZ, financing resource, and enterprise performance for (1), two step $\mathrm{GMM}^{\S}$

\begin{tabular}{|c|c|c|c|c|c|c|}
\hline Two step GMM & \multicolumn{3}{|c|}{$\begin{array}{c}\text { Dependent variable }=\ln (\text { value } \\
\text { added })\end{array}$} & \multicolumn{3}{|c|}{ Dependent variable $=$ sales growth } \\
\hline Column & 1 & 2 & 3 & 4 & 5 & 6 \\
\hline cluster 1 & $\begin{array}{l}0.368 * * * \\
(4.69)\end{array}$ & $\begin{array}{l}0.504 * * * \\
(5.15)\end{array}$ & $\begin{array}{c}0.367 * * * \\
(4.55)\end{array}$ & $\begin{array}{l}0.050^{*} \\
(1.86)\end{array}$ & $\begin{array}{c}0.044^{*} \\
(1.71)\end{array}$ & $\begin{array}{c}0.043^{*} \\
(1.81)\end{array}$ \\
\hline cluster2 & $\begin{array}{l}0.010 \\
(0.20)\end{array}$ & $\begin{array}{l}0.050 \\
(0.85)\end{array}$ & $\begin{array}{l}0.026 \\
(0.49)\end{array}$ & $\begin{array}{c}0.064 * * * \\
(3.30)\end{array}$ & $\begin{array}{l}0.045 * * \\
(2.33)\end{array}$ & $\begin{array}{l}0.061 * * * \\
(3.16)\end{array}$ \\
\hline net trade credit $_{t-1}$ & $\begin{array}{c}0.969 * * \\
(2.03)\end{array}$ & & $\begin{array}{c}1.381 * * \\
(2.06)\end{array}$ & $\begin{array}{c}.483 * * * \\
(3.91)\end{array}$ & & $\begin{array}{l}.251 * * * \\
(3.10)\end{array}$ \\
\hline bank $\operatorname{loan}_{\mathrm{t}-1}$ & & $\begin{array}{l}0.096 \\
(0.94)\end{array}$ & $\begin{array}{c}1.153 * * \\
(2.36)\end{array}$ & & $\begin{array}{c}0.223 * * \\
(1.97)\end{array}$ & $\begin{array}{l}0.255^{* * * *} \\
(2.67)\end{array}$ \\
\hline age & $\begin{array}{l}-0.002 \\
(-0.97)\end{array}$ & $\begin{array}{l}-0.001 \\
(-0.54)\end{array}$ & $\begin{array}{l}-0.003 * \\
(-1.80)\end{array}$ & $\begin{array}{c}-0.002 * * * \\
(-2.67)\end{array}$ & $\begin{array}{l}-0.002 * \\
(-1.82)\end{array}$ & $\begin{array}{l}-0.002^{*} \\
(-1.83)\end{array}$ \\
\hline liquidity $_{\mathrm{t}-1}$ & $\begin{array}{c}0.624 * * \\
(2.30)\end{array}$ & $\begin{array}{l}0.677 \\
(1.49)\end{array}$ & $\begin{array}{c}1.181 * * \\
(2.36)\end{array}$ & $\begin{array}{l}0.138 \\
(0.86)\end{array}$ & $\begin{array}{l}-0.057 \\
(-0.37)\end{array}$ & $\begin{array}{l}-0.073 \\
(-0.56)\end{array}$ \\
\hline net profit ${ }_{\mathrm{t}-1}$ & $\begin{array}{l}3.822 * * * \\
(4.91)\end{array}$ & $\begin{array}{l}3.648 * * * \\
(5.29)\end{array}$ & $\begin{array}{l}3.987 * * * \\
(4.93)\end{array}$ & $\begin{array}{l}-0.431 \\
(-0.91)\end{array}$ & $\begin{array}{l}-0.031 \\
(-0.13)\end{array}$ & $\begin{array}{l}-0.034 \\
(-0.20)\end{array}$ \\
\hline large-sized enterprise & $\begin{array}{l}0.345 * * * \\
(3.50)\end{array}$ & $\begin{array}{c}0.426 * * \\
(2.23)\end{array}$ & $\begin{array}{c}0.306 * * * \\
(3.46)\end{array}$ & $\begin{array}{l}0.044 \\
(1.24)\end{array}$ & $\begin{array}{c}0.038^{*} \\
(1.82)\end{array}$ & $\begin{array}{l}0.046 \\
(1.58)\end{array}$ \\
\hline SME & $\begin{array}{c}-0.242 * * * \\
(-3.98)\end{array}$ & $\begin{array}{c}-0.352 * * \\
(-2.03)\end{array}$ & $\begin{array}{c}-0.200 * * * \\
(-3.24)\end{array}$ & $\begin{array}{c}-0.243 * * * \\
(-3.56)\end{array}$ & $\begin{array}{c}-0.031 * * * \\
(-3.40)\end{array}$ & $\begin{array}{l}-0.045 \\
(-1.54)\end{array}$ \\
\hline foreign share & $\begin{array}{l}0.002 \\
(0.02)\end{array}$ & $\begin{array}{l}0.103 \\
(1.37)\end{array}$ & $\begin{array}{l}0.102 \\
(1.41)\end{array}$ & $\begin{array}{l}0.005 \\
(0.19)\end{array}$ & $\begin{array}{c}0.045^{*} \\
(1.81)\end{array}$ & $\begin{array}{l}0.030 \\
(1.22)\end{array}$ \\
\hline private share & $\begin{array}{l}-0.044 \\
(-0.72)\end{array}$ & $\begin{array}{c}-0.181 * * * \\
(-2.90)\end{array}$ & $\begin{array}{l}-0.090 \\
(-1.31)\end{array}$ & $\begin{array}{c}0.048 * * \\
(2.14)\end{array}$ & $\begin{array}{l}0.037 \\
(1.21)\end{array}$ & $\begin{array}{l}0.022 \\
(1.01)\end{array}$ \\
\hline $\ln (\text { fixed asset })_{t-1}$ & $\begin{array}{c}0.370 * * * \\
(15.11)\end{array}$ & $\begin{array}{c}0.267 * * * \\
(3.03)\end{array}$ & $\begin{array}{c}0.393 * * * \\
(13.60)\end{array}$ & & & \\
\hline $\ln (\text { labor })_{t-1}$ & $\begin{array}{c}0.404 * * * \\
(12.78)\end{array}$ & $\begin{array}{c}0.454 * * * \\
(3.29)\end{array}$ & $\begin{array}{c}0.403 * * * \\
(11.92)\end{array}$ & & & \\
\hline industry dummy & yes & yes & yes & yes & yes & yes \\
\hline city dummy & yes & yes & yes & yes & yes & yes \\
\hline year dummy & yes & yes & yes & yes & yes & yes \\
\hline constant & $\begin{array}{l}1.121 * \\
(1.87)\end{array}$ & $\begin{array}{c}1.243 * * \\
(2.23)\end{array}$ & $\begin{array}{l}1.411^{*} \\
(1.83)\end{array}$ & $\begin{array}{c}0.449 * * * \\
(7.09)\end{array}$ & $\begin{array}{c}0.317 * * \\
(1.96)\end{array}$ & $\begin{array}{l}-0.051 \\
(-0.47)\end{array}$ \\
\hline p-value of Hansen test & 0.448 & 0.316 & 0.290 & 0.275 & 0.215 & 0.073 \\
\hline $\operatorname{AR}(2)$ & 0.104 & 0.259 & 0.215 & 0.102 & 0.811 & 0.777 \\
\hline No. Obs & 6030 & 6030 & 6030 & 6030 & 6030 & 6030 \\
\hline
\end{tabular}

$\S$ The table presents Blundel and Bond's two-step system GMM results. The dependent variables are ln(value added) and sales growth, as indicated. 
The values in parentheses are the t statistic based on Windmeijer (2005)'s finite sample correction for standard errors in the two step estimation.

$*$ Significant at $10 \%$. ** Significant at 5\%.***Significant at $1 \%$.

\subsection{The Role of HNTIDZ}

Given that improved access to trade credit and bank loan enable HNT enterprise to improve productivity, how does clustering affect the relationship between finance and enterprise activity? In other words, could enterprises within HNTIDZs perform better if they obtained more external financing? To investigate this question, we calculated estimates for (3), including the interaction terms of the cluster dummy, net trade credit, and bank loan variables, as shown in Table 3.

For any specification, the Hansen test of overidentifying restrictions cannot be rejected and the AR (2) test also confirms that serial correlation of $\varepsilon_{\text {it }}$ does not hold, hence all instrumental variables we used were exogenous and valid.

Table 3 columns 1-3 show that interaction of cluster1, net trade credit, and bank loan are associated with significantly positive coefficient, suggesting that national HNTIDZs and external financing sources reinforce each other in promoting enterprise productivity. That is, through industrial agglomeration, increased enterprises' financing flexibility within national HNTIDZs could provide greater productivity than those outside the HNTIDZs. Similar results are shown in columns 4-6. The coefficients for interaction of cluster1, net trade credit, and bank loan are significantly positive, indicating that more financing for enterprises within national HNTIDZs achieves more rapid sales growth.

The impact of national HNTIDZs cannot be ignored. A significant body of literature shows the advantages of industrial clusters. Marshall (1920) pioneered three key benefits of industrial clusters: more efficient labor division and lower prices by means of input specification, labor pooling, and sharing information and knowledge. Many empirical studies have shown that sharing information and knowledge stimulates technology spillovers, leading to increased enterprise productivity and competitive advantage (Almeida and Kogut, 1999; Audretsch and Feldman, 2004; Porter, 1998; Ciccone and Hall, 1996; Ciccone, 2002). As discussed in Section 2, although HNTIDZs are artificial industrial clusters, their effects are similar. Enterprises within HNTIDZs produce homogenous products and generate technology spillovers, which results in lower intermediate cost, more healthy competition, and stronger innovation capacity. All of these advantages are conducive to higher returns on financing resource. This may be the underlying reason for different returns of the two groups of enterprises (within and outside the HNTIDZ) in spite of the same amount of financing resource obtained. This is consistent with Long and Zhang (2011), who also show that industries that are more in need of external finance and trade credit are more productive in areas with higher clustering levels.

The influences of enterprise characteristics are consistent with Table 2. The number of employees, net value of fixed assets, enterprise size, and net profit are positively and significantly connected with enterprise productivity. 
Table 3. HNTIDZ, financing resource, and enterprise performance for (3): two step GMM $^{\S}$

\begin{tabular}{|c|c|c|c|c|c|c|}
\hline \multirow{2}{*}{$\begin{array}{l}\text { Two step GMM } \\
\text { Column }\end{array}$} & \multicolumn{3}{|c|}{ Dependent variable $=\ln ($ value added $)$} & \multicolumn{3}{|c|}{ Dependent variable $=$ sales growth } \\
\hline & 1 & 2 & 3 & 4 & 5 & 6 \\
\hline \multirow[t]{2}{*}{ clu $1 *$ net trade credit ${ }_{\mathrm{t}-1}$} & $0.375 * *$ & & $0.908 * * *$ & $0.573 * *$ & & $0.254 * *$ \\
\hline & $(2.32)$ & & $(2.62)$ & $(2.45)$ & & $(2.42)$ \\
\hline \multirow[t]{2}{*}{ clu $2 *$ net trade credit $_{\mathrm{t}-1}$} & -0.070 & & -0.146 & $0.312 *$ & & 0.106 \\
\hline & $(-0.47)$ & & $(-0.73)$ & $(1.80)$ & & $(0.85)$ \\
\hline \multirow[t]{2}{*}{ clu $1 *$ bank $\operatorname{loan}_{\mathrm{t}-1}$} & & $5.284 *$ & $0.546 * *$ & & 0.710 & $0.268^{*}$ \\
\hline & & $(1.91)$ & $(2.42)$ & & $(1.24)$ & $(1.76)$ \\
\hline \multirow[t]{2}{*}{ clu $2 *$ bank $\operatorname{loan}_{\mathrm{t}-1}$} & & 3.044 & -0.057 & & $0.751 *$ & -0.025 \\
\hline & & $(1.47)$ & $(-0.36)$ & & $(1.77)$ & $(-0.19)$ \\
\hline \multirow[t]{2}{*}{ cluster1 } & $0.353 * * *$ & -1.119 & $0.403 * * *$ & $0.049 *$ & -0.205 & -0.045 \\
\hline & $(4.96)$ & $(-1.53)$ & $(3.78)$ & $(1.84)$ & $(-1.29)$ & $(-1.00)$ \\
\hline \multirow[t]{2}{*}{ cluster2 } & -0.002 & -1.062 & 0.065 & $0.068 * * *$ & -0.224 & 0.056 \\
\hline & $(-0.05)$ & $(-1.47)$ & $(0.87)$ & $(2.83)$ & $(-1.46)$ & (1.07) \\
\hline \multirow{2}{*}{ net trade credit $_{t-1}$} & $0.255^{*} * *$ & & $0.213 *$ & $0.210 * * *$ & & 0.029 \\
\hline & $(2.82)$ & & $(1.93)$ & $(2.60)$ & & $(0.47)$ \\
\hline \multirow{2}{*}{ bank $\operatorname{loan}_{\mathrm{t}-1}$} & & -1.122 & $2.078^{*}$ & & -0.401 & 0.061 \\
\hline & & $(-0.76)$ & $(1.72)$ & & $(-0.97)$ & $(0.57)$ \\
\hline \multirow[t]{2}{*}{ age } & -0.002 & -0.0005 & -0.001 & $-0.002 * * *$ & -0.001 & $-0.002 *$ \\
\hline & $(-1.31)$ & $(-0.17)$ & $(-0.35)$ & $(-2.89)$ & $(-1.25)$ & $(-1.88)$ \\
\hline \multirow{2}{*}{ liquidity $_{\mathrm{t}-1}$} & $1.100 * *$ & $1.637 * *$ & $0.810 *$ & -0.056 & -0.170 & -0.231 \\
\hline & $(2.50)$ & $(2.19)$ & $(1.71)$ & $(-0.51)$ & $(-1.11)$ & $(-1.01)$ \\
\hline \multirow[t]{2}{*}{ net profit ${ }_{t-1}$} & $3.680 * * *$ & $4.883 * * *$ & $3.563 * * *$ & 0.327 & 0.301 & -0.074 \\
\hline & $(5.56)$ & (2.79) & (5.14) & $(0.99)$ & (1.04) & $(-0.44)$ \\
\hline \multirow[t]{2}{*}{ large-sized enterprise } & $0.334 * * *$ & $0.367 * * *$ & $0.410 * *$ & 0.003 & 0.024 & 0.022 \\
\hline & $(4.13)$ & (3.22) & $(2.16)$ & $(0.09)$ & $(1.23)$ & $(1.10)$ \\
\hline \multirow[t]{2}{*}{ SME } & $-0.258 * * *$ & $-0.270 * *$ & $-0.351 * *$ & $-0.208 * * *$ & $-0.190 * * *$ & $-0.234 * * *$ \\
\hline & $(-4.57)$ & $(-2.41)$ & $(-2.02)$ & $(-3.31)$ & $(-4.10)$ & $(-4.39)$ \\
\hline \multirow[t]{2}{*}{ foreign share } & 0.067 & 0.236 & 0.096 & 0.006 & 0.010 & 0.012 \\
\hline & (1.08) & $(1.30)$ & $(1.31)$ & $(0.29)$ & $(0.26)$ & $(0.40)$ \\
\hline \multirow[t]{2}{*}{ private share } & $-0.126^{* *}$ & -0.082 & $-0.171 * * *$ & 0.029 & 0.013 & 0.014 \\
\hline & $(-2.36)$ & $(-1.05)$ & $(-2.81)$ & $(1.35)$ & $(0.57)$ & $(0.49)$ \\
\hline $\ln (\text { fixed asset })_{t-1}$ & $\begin{array}{c}0.442 * * * \\
(933)\end{array}$ & $\begin{array}{l}0.399 * * \\
(240)\end{array}$ & $0.272 * * *$ & & & \\
\hline \multirow[t]{2}{*}{$\ln (\text { labor })_{\mathrm{t}-1}$} & $0.342 * * *$ & $0.403 * * *$ & $0.442 * * *$ & & & \\
\hline & (8.81) & $(3.14)$ & $(3.12)$ & & & \\
\hline industry dummy & yes & yes & yes & yes & yes & yes \\
\hline city dummy & yes & yes & yes & yes & yes & yes \\
\hline year dummy & yes & yes & yes & yes & yes & yes \\
\hline \multirow[t]{2}{*}{ constant } & $2.105 * * *$ & $3.141 *$ & $4.344 * * *$ & $.405 * * *$ & $.469 * *$ & $.403 * *$ \\
\hline & $(3.48)$ & (1.88) & $(4.18)$ & $(7.31)$ & $(2.11)$ & $(2.11)$ \\
\hline p-value of Hansen test & 0.352 & 0.305 & 0.305 & 0.491 & 0.434 & 0.209 \\
\hline $\mathrm{AR}(2)$ & 0.150 & 0.226 & 0.232 & 0.105 & 0.865 & 0.905 \\
\hline No. Obs & 6030 & 6030 & 6030 & 6030 & 6030 & 6030 \\
\hline
\end{tabular}

$\S$ The table presents Blundel and Bond's two step GMM results. The dependent variables are $\ln ($ value added) and sales growth, as indicated.

The values in parentheses are the t statistic based on Windmeijer (2005)'s finite sample correction for standard errors in the two step estimation.

*Significant at $10 \%$. ** Significant at $5 \%$. ***Significant at $1 \%$.

\subsection{HNTIDZ and Financial Effect on Export and Innovation}

We investigated whether industrial agglomeration affects export and new product output value. Many HNT enterprises within HNTIDZs benefit from preferential policies, such as income tax reduction and export or import tariff exemptions, allowing them to more easily cooperate with overseas enterprises to manufacture exported oriented products. It is particularly meaningful to estimate new product output as this is the crux for development of HNT industry because new product development represents innovation ability and potential. Table 4 shows estimations for (2) based on the Tobit model with random effects. Columns 1-3 show estimates using export as the dependent variable, and columns 46 use new product output value as the dependent variable. The likelihood ratio (LR) test shows individual heterogeneity exists in the estimation, indicating that the Tobit model with random effects is appropriate. 
Regardless of cluster1 or cluster2, the cluster dummy has significantly positive coefficient. Thus, compared with enterprises outside HNTIDZs, enterprises located in national and provincial HNTIDZs had a marked preponderance in export delivery value and new product output, indicating that industrial agglomeration plays a great role in fostering enterprise export performance and innovation ability. This is consistent with the firm level studies of Zhang (2015) and Ito et al. (2013), who found a positive influence of agglomeration on product innovation and export entry in China.

We also observe that net trade credit and bank loan are significantly and positively connected with export, while the coefficients for both become insignificant when the dependent variable is replaced by new product output. This shows that enterprises with more external financing resource exhibit better export performance. Some researches (Beck, 2002; Hur et al., 2006) have shown a possible positive association between financial development and international trade. However, external financing resource does not work for innovation input, implying that capital obtained is inadequate to support enterprise innovation activity.

The coefficients of other control variables are consistent with previous findings. Sales have a significantly positive impact on export and new product output. Large enterprises have particularly high significance for both export and new product output, which implies that larger enterprises are more capable of export business and institute new product research thanks to their abundant assets, rich experience, as well as qualified technicians.

Table 4. HNTIDZ, financing resource, and enterprise performance for (2): random effects Tobit model ${ }^{\S}$

\begin{tabular}{|c|c|c|c|c|c|c|}
\hline $\begin{array}{l}\text { Random effects Tobit } \\
\text { regression }\end{array}$ & \multicolumn{3}{|c|}{$\begin{array}{c}\text { Dependent variable }=\text { export/total } \\
\text { asset }\end{array}$} & \multicolumn{3}{|c|}{ Dependent variable $=\mathrm{npd} /$ total asset } \\
\hline Column & 1 & 2 & 3 & 4 & 5 & 6 \\
\hline cluster1 & $\begin{array}{c}0.419 * * * \\
(3.73)\end{array}$ & $\begin{array}{c}0.382 * * * \\
(3.29)\end{array}$ & $\begin{array}{c}0.430 * * * \\
(3.75)\end{array}$ & $\begin{array}{c}0.583 * * * \\
(3.20)\end{array}$ & $\begin{array}{c}0.503 * * * \\
(2.78)\end{array}$ & $\begin{array}{c}0.589 * * * \\
(3.23)\end{array}$ \\
\hline cluster2 & $\begin{array}{l}.226^{* *} \\
(2.42)\end{array}$ & $\begin{array}{l}0.182^{*} \\
(1.87)\end{array}$ & $\begin{array}{c}0.237 * * \\
(2.51)\end{array}$ & $\begin{array}{c}0.313^{* *} \\
(2.21)\end{array}$ & $\begin{array}{c}0.276^{* *} \\
(1.96)\end{array}$ & $\begin{array}{c}0.316^{* *} \\
(2.22)\end{array}$ \\
\hline net trade credit $_{\mathrm{t}-1}$ & $\begin{array}{l}0.346^{* * * *} \\
(3.71)\end{array}$ & & $\begin{array}{l}0.399 * * * \\
(4.04)\end{array}$ & $\begin{array}{l}0.311 \\
(1.42)\end{array}$ & & $\begin{array}{l}0.343 \\
(1.52)\end{array}$ \\
\hline bank $\operatorname{loan}_{\mathrm{t}-1}$ & & $\begin{array}{l}0.006 \\
(0.07)\end{array}$ & $\begin{array}{c}0.212^{*} \\
(1.69)\end{array}$ & & $\begin{array}{l}-0.070 \\
(-0.34)\end{array}$ & $\begin{array}{l}0.160 \\
(0.57)\end{array}$ \\
\hline age & $\begin{array}{c}0.0004 \\
(0.20)\end{array}$ & $\begin{array}{c}-0.0006 \\
(-0.29)\end{array}$ & $\begin{array}{l}0.002 \\
(0.74)\end{array}$ & $\begin{array}{l}0.003 \\
(0.75)\end{array}$ & $\begin{array}{l}0.004 \\
(0.84)\end{array}$ & $\begin{array}{l}0.003 \\
(0.71)\end{array}$ \\
\hline liquidity $_{\mathrm{t}-1}$ & $\begin{array}{c}0.304^{* *} \\
(2.51)\end{array}$ & $\begin{array}{l}0.270^{* *} \\
(2.26)\end{array}$ & $\begin{array}{l}0.347 * * * \\
(2.85)\end{array}$ & $\begin{array}{l}0.152 \\
(0.61)\end{array}$ & $\begin{array}{l}0.194 \\
(0.78)\end{array}$ & $\begin{array}{l}0.169 \\
(0.68)\end{array}$ \\
\hline sales $_{\mathrm{t}-1}$ & $\begin{array}{l}0.239 * * * \\
(13.54)\end{array}$ & $\begin{array}{c}0.219 * * * \\
(12.37)\end{array}$ & $\begin{array}{c}0.246^{* * * *} \\
(13.93)\end{array}$ & $\begin{array}{l}0.081^{* *} \\
(2.32)\end{array}$ & $\begin{array}{l}0.092 * * * \\
(2.66)\end{array}$ & $\begin{array}{c}0.083^{* *} \\
(2.36)\end{array}$ \\
\hline large-sized enterprise & $\begin{array}{c}0.366^{* * * *} \\
(4.05)\end{array}$ & $\begin{array}{c}0.263 * * * \\
(10.01)\end{array}$ & $\begin{array}{c}0.361 * * * \\
(3.99)\end{array}$ & $\begin{array}{l}0.751 * * * \\
(4.52)\end{array}$ & $\begin{array}{l}0.493 * * * \\
(2.87)\end{array}$ & $\begin{array}{l}0.748^{* * *} \\
(4.50)\end{array}$ \\
\hline SME & $\begin{array}{c}-0.239 * * * \\
(-3.42)\end{array}$ & $\begin{array}{c}-0.804 * * * \\
(-7.18)\end{array}$ & $\begin{array}{c}-0.235 * * * \\
(-3.35)\end{array}$ & $\begin{array}{l}-0.499 \\
(-0.73)\end{array}$ & $\begin{array}{c}-0.661 * * * \\
(-5.03)\end{array}$ & $\begin{array}{l}-0.490 \\
(-0.72)\end{array}$ \\
\hline foreign share & $\begin{array}{c}0.826 * * * \\
(7.86)\end{array}$ & $\begin{array}{c}0.771 * * * \\
(7.20)\end{array}$ & $\begin{array}{c}0.846^{* * * *} \\
(7.88)\end{array}$ & $\begin{array}{c}-0.795^{* * * *} \\
(-4.23)\end{array}$ & $\begin{array}{c}-0.886^{* * *} \\
(-4.64)\end{array}$ & $\begin{array}{c}-0.777 * * * \\
(-4.08)\end{array}$ \\
\hline private share & $\begin{array}{l}0.080 \\
(0.94)\end{array}$ & $\begin{array}{l}0.097 \\
(1.15)\end{array}$ & $\begin{array}{l}0.071 \\
(0.84)\end{array}$ & $\begin{array}{l}-0.163 \\
(-1.10)\end{array}$ & $\begin{array}{l}-0.148 \\
(-1.01)\end{array}$ & $\begin{array}{l}-0.165 \\
(-1.12)\end{array}$ \\
\hline industry dummy & yes & yes & yes & yes & yes & yes \\
\hline city dummy & yes & yes & yes & yes & yes & yes \\
\hline year dummy & yes & yes & yes & yes & yes & yes \\
\hline constant & $\begin{array}{c}-1.023 * * \\
(-2.36)\end{array}$ & $\begin{array}{c}-2.571 * * * \\
(-5.53)\end{array}$ & $\begin{array}{c}-1.193 * * * \\
(-2.73)\end{array}$ & $\begin{array}{c}-2.044 * * * \\
(-3.37)\end{array}$ & $\begin{array}{c}-1.475 * * \\
(-2.39)\end{array}$ & $\begin{array}{c}--2.122 * * * \\
(--3.41)\end{array}$ \\
\hline No. Obs & 6030 & 6030 & 6030 & 6030 & 6030 & 6030 \\
\hline LR test & 2605.53 & 2779.13 & 2597.97 & 752.15 & 729.75 & 752.20 \\
\hline $\begin{array}{l}\text { uncensored } \\
\text { observations }\end{array}$ & 2482 & 2482 & 2482 & 800 & 800 & 800 \\
\hline
\end{tabular}

$\S$ The table presents random effects Tobit model results. The dependent variables are export delivery value/total assets and new product output/total assets, as indicated.

The values in parentheses are the $t$ value.

*Significant at $10 \%$.** Significant at $5 \%$.***Significant at $1 \%$.

\subsection{The Role of HNTIDZ}

To investigate the effect of industrial agglomeration on enterprise export and innovation performance when obtaining finance, we used the same specification as (4), replacing $\ln$ (value added) and sales growth rate with export delivery 
value and new product output, respectively. Table 5 shows the estimation results. LR tests show that the Tobit model with random effects cannot be rejected as individual heterogeneity occurs for any specification.

Columns 1-3 show the estimates for export as the dependent variable. The interaction terms of cluster dummies (cluster1 and cluster2), net trade credit, and bank loan have positive and significant influences on export, showing that regardless of whether receiving an increase in net trade credit or bank loan, enterprises within HNTIDZs are more likely to achieve superior export performance. In other words, industrial agglomeration effect weakens the impact of financing on export. We also found that the impact of net trade credit and bank loan on new product output was insignificant in Table 4. However, Table 5, columns 4-6 show that the coefficients for the interaction term of cluster1 dummy, trade credit and bank loan are significantly positive, which suggests that better utilization of financing for enterprises located within national HNTIDZs tended to boost new product output. Therefore, industrial agglomeration in the form of HNTIDZs provides HNT enterprises with an excellent way to apply finance, aiming for cultivation of innovation ability.

Table 5. HNTIDZ, financing resource, and enterprise performance for (4): random effect Tobit model ${ }^{\S}$

\begin{tabular}{|c|c|c|c|c|c|c|}
\hline \multirow{2}{*}{$\begin{array}{l}\text { Random effects Tobit } \\
\text { regression } \\
\text { Column } \\
\end{array}$} & \multicolumn{3}{|c|}{$\begin{array}{c}\text { Dependent variable }=\text { export/total } \\
\text { asset }\end{array}$} & \multicolumn{3}{|c|}{ Dependent variable $=$ npd/total asset } \\
\hline & 1 & 2 & 3 & 4 & 5 & 6 \\
\hline clu $1 *$ net trade credit $_{t-1}$ & $\begin{array}{c}0.827 * * * \\
(3.43)\end{array}$ & & $\begin{array}{c}1.059 * * * \\
(4.20)\end{array}$ & $\begin{array}{c}1.934 * * * \\
(2.95)\end{array}$ & & $\begin{array}{l}1.233^{*} \\
(1.81)\end{array}$ \\
\hline clu $2 *$ net trade credit $_{t-1}$ & $\begin{array}{c}0.556^{* *} \\
(2.31)\end{array}$ & & $\begin{array}{c}0.670 * * \\
(2.53)\end{array}$ & $\begin{array}{l}0.372 \\
(0.76)\end{array}$ & & $\begin{array}{l}-0.221 \\
(-0.40)\end{array}$ \\
\hline clu1*bank $\operatorname{loan}_{\mathrm{t}-1}$ & & $\begin{array}{l}0.389 * \\
(1.67)\end{array}$ & $\begin{array}{l}0.767 * * * \\
(2.83)\end{array}$ & & $\begin{array}{c}1.021 * * \\
(2.08)\end{array}$ & $\begin{array}{c}0.967^{*} \\
(1.76)\end{array}$ \\
\hline clu2*bank loan ${ }_{t-1}$ & & $\begin{array}{l}-0.036 \\
(-0.17)\end{array}$ & $\begin{array}{l}0.238 \\
(1.02)\end{array}$ & & $\begin{array}{l}0.247 \\
(0.61)\end{array}$ & $\begin{array}{l}-0.307 \\
(-0.66)\end{array}$ \\
\hline cluster1 & $\begin{array}{l}0.194 \\
(1.52)\end{array}$ & $\begin{array}{c}0.320 * * \\
(2.41)\end{array}$ & $\begin{array}{l}-0.062 \\
(-0.39)\end{array}$ & $\begin{array}{l}0.577 * * * \\
(3.22)\end{array}$ & $\begin{array}{l}0.050 \\
(0.22)\end{array}$ & $\begin{array}{l}0.137 \\
(0.57)\end{array}$ \\
\hline cluster2 & $\begin{array}{l}0.093 \\
(0.88)\end{array}$ & $\begin{array}{c}0.242 * * \\
(2.02)\end{array}$ & $\begin{array}{l}-0.011 \\
(-0.07)\end{array}$ & $\begin{array}{c}0.443^{* * * *} \\
(3.02)\end{array}$ & $\begin{array}{l}0.338^{*} \\
(1.68)\end{array}$ & $\begin{array}{c}0.455^{* *} \\
(2.11)\end{array}$ \\
\hline net trade credit $_{t-1}$ & $\begin{array}{l}.230 * * \\
(2.05)\end{array}$ & & $\begin{array}{l}.223^{*} \\
(1.95)\end{array}$ & $\begin{array}{l}-.553 \\
(-0.66)\end{array}$ & & $\begin{array}{l}.110 \\
(0.36)\end{array}$ \\
\hline bank $\operatorname{loan}_{\mathrm{t}-1}$ & & $\begin{array}{l}-0.095 \\
(-0.74)\end{array}$ & $\begin{array}{l}-0.050 \\
(-0.35)\end{array}$ & & $\begin{array}{l}-0.178 \\
(-0.67)\end{array}$ & $\begin{array}{l}0.001 \\
(0.00)\end{array}$ \\
\hline age & $\begin{array}{l}0.001 \\
(0.62)\end{array}$ & $\begin{array}{l}0.002 \\
(0.81)\end{array}$ & $\begin{array}{l}0.002 \\
(0.78)\end{array}$ & $\begin{array}{l}0.003 \\
(0.58)\end{array}$ & $\begin{array}{l}0.010 * * * \\
(2.91)\end{array}$ & $\begin{array}{l}0.005 \\
(1.11)\end{array}$ \\
\hline liquidity $_{\mathrm{t}-1}$ & $\begin{array}{l}0.257 * * \\
(2.02)\end{array}$ & $\begin{array}{l}0.286^{* *} \\
(2.36)\end{array}$ & $\begin{array}{c}0.252^{* *} \\
(1.97)\end{array}$ & $\begin{array}{l}0.070 \\
(0.26)\end{array}$ & $\begin{array}{l}0.133 \\
(0.59)\end{array}$ & $\begin{array}{l}0.089 \\
(0.36)\end{array}$ \\
\hline sales $_{\mathrm{t}-1}$ & $\begin{array}{c}0.209 * * * \\
(11.52)\end{array}$ & $\begin{array}{l}0.240 * * * \\
(13.52)\end{array}$ & $\begin{array}{c}0.210^{* * *} \\
(11.59)\end{array}$ & $\begin{array}{l}0.123 * * * \\
(3.36)\end{array}$ & $\begin{array}{l}0.225 * * * \\
(7.06)\end{array}$ & $\begin{array}{l}0.112 * * * \\
(3.21)\end{array}$ \\
\hline large-sized enterprise & $\begin{array}{c}0.368 * * * \\
(4.07)\end{array}$ & $\begin{array}{l}0.384 * * * \\
(4.23)\end{array}$ & $\begin{array}{l}0.359 * * * \\
(3.97)\end{array}$ & $\begin{array}{l}0.305^{* *} \\
(2.46)\end{array}$ & $\begin{array}{c}0.399 * * \\
(2.52)\end{array}$ & $\begin{array}{c}0.362 * * \\
(2.11)\end{array}$ \\
\hline SME & $\begin{array}{c}-0.212 * * * \\
(-3.05)\end{array}$ & $\begin{array}{c}-0.233 * * * \\
(-3.29)\end{array}$ & $\begin{array}{c}-0.215^{* * *} * \\
(-3.10)\end{array}$ & $\begin{array}{l}-0.398 \\
(-0.55)\end{array}$ & $\begin{array}{c}-0.536^{* * * *} \\
(-4.42)\end{array}$ & $\begin{array}{c}-0.613 * * * \\
(-4.66)\end{array}$ \\
\hline foreign share & $\begin{array}{c}0.851 * * * \\
(8.04)\end{array}$ & $\begin{array}{c}0.840 * * * \\
(7.75)\end{array}$ & $\begin{array}{c}0.873 * * * \\
(8.21)\end{array}$ & $\begin{array}{c}-0.918 * * * \\
(-4.91)\end{array}$ & $\begin{array}{c}-0.822 * * * \\
(-4.61)\end{array}$ & $\begin{array}{c}-1.007 * * * \\
(-5.34)\end{array}$ \\
\hline private share & $\begin{array}{l}0.037 \\
(0.44)\end{array}$ & $\begin{array}{l}0.077 \\
(0.90)\end{array}$ & $\begin{array}{l}0.042 \\
(0.49)\end{array}$ & $\begin{array}{l}-0.178 \\
(-1.19)\end{array}$ & $\begin{array}{l}-0.061 \\
(-0.47)\end{array}$ & $\begin{array}{l}-0.114 \\
(-0.78)\end{array}$ \\
\hline industry dummy & yes & yes & yes & yes & yes & yes \\
\hline city dummy & yes & yes & yes & yes & yes & yes \\
\hline year dummy & yes & yes & yes & yes & yes & yes \\
\hline constant & $\begin{array}{c}-0.926^{* *} \\
(-2.18)\end{array}$ & $\begin{array}{c}-1.116^{* *} \\
(-2.51)\end{array}$ & $\begin{array}{c}-.915 * * \\
(-2.13)\end{array}$ & $\begin{array}{c}-1.751 * * * \\
(-6.96)\end{array}$ & $\begin{array}{c}-1.323 * * \\
(-2.15)\end{array}$ & $\begin{array}{c}-1.624 * * * \\
(-5.41)\end{array}$ \\
\hline No. Obs & 6030 & 6030 & 6030 & 6030 & 6030 & 6030 \\
\hline LR test & 2387.81 & 2684.12 & 2386.28 & 738.56 & 1016.54 & 719.04 \\
\hline $\begin{array}{l}\text { uncensored } \\
\text { observations }\end{array}$ & 2482 & 2482 & 2482 & 800 & 800 & 800 \\
\hline
\end{tabular}

$\S_{\text {The }}$ table presents random-effects Tobit model results. The dependent variables are export delivery value/total assets and new product output/total assets, as indicated.

The values in parentheses are the $\mathrm{t}$ value.

*Significant at $10 \%$. ** Significant at $5 \%$. ***Significant at $1 \%$ 


\section{Conclusions}

Using 2002-2009 firm level data for enterprises in Yangtze River Delta (incorporating Jiangsu Province, Zhejiang Province, and Shanghai Municipality), we examined the impact of HNTIDZs and financial resource in stimulating enterprise performance. We considered HNTIDZ importance to the relationship between financial resource and enterprise performance. The main results are summarized as follows.

1. Previous studies found that traditional industrial clusters and agglomerations were conducive to improving Chinese manufacturing enterprise performance, and the current findings provide new support for the effect of government led industrial clusters (HNTIDZs). Enterprises within HNTIDZs have superior performance in terms of productivity, sales growth, export, and innovation activity. This suggests that government led industrial clusters also play a significant role in promoting enterprise performance.

2. Trade credit and bank loan both exert a large and robust positive influence on enterprise productivity, sales growth, and export, including a range of controls. However, they do not have an effect on innovative activity. This could be due to inadequate financing resource provided by business partners and banks to develop new products.

3. Compared to the enterprises outside HNTIDZs, those within national HNTIDZs have higher returns in respect of productivity, sales growth, export, and innovative activity from trade credit and bank loans. Thus, national HNTIDZs are conducive to more effective utilization of formal and informal financing resource to achieve better enterprise performance.

\section{Reference}

Allen, F., Qian, J., \& Qian, M. (2005). Law,finance, and economic growth in China. Journal of Financial Economics, 77(1), 57-116. https://doi.org/10.1016/j.jfineco.2004.06.010

Almeida, P., \& Kogut, B. (1999), Localization of knowledge and the mobility of engineers in regional networks. Management Science, 45(7), 905-917. https://doi.org/10.1287/mnsc.45.7.905

Arellano, M., \& Bond, S. (1991). Some tests of specification for panel data: Monte Carlo evidence and an alication to employment equation. Review of Economic Studies, 58, 277-298. https://doi.org/10.2307/2297968

Audretsch, D. B., \& Feldman, M. P. (2004). Knowledge Spillovers and the Geography of Innovation. Handbook of Urban and Regional Economics 4, 2713-2739. https://doi.org/10.1016/S1574-0080(04)80018-X

Ayyagari, M. A., Demirgüc, K., \& Maksimovic, V. (2010). Formal versus informal finance: evidence from China. Review of Financial Studies, 23(8), 3048-3097. https://doi.org/10.1093/rfs/hhq030

Bai, C. E. Y., Du, Z. T., \& Tong, S. Y. (2004). Local protectionism and regional specialization: Evidence from China's industries. Journal of International Economics, 63(2), 397-417. https://doi.org/10.1016/S0022-1996(03)00070-9

Beck, T. (2002). Financial development and international trade: Is there a link? Journal of International Economics 57(1), 107-131. https://doi.org/10.1016/S0022-1996(01)00131-3

Biesebroeck, J. V. (2005). Firm size matters: Growth and productivity growth in African manufacturing. Economic Development and Cultural Change, 53, 545-583. https://doi.org/10.1086/426407

Blundell, R., \& Bond, S. (1998). Initial conditions and moment restrictions in dynamic panel data models. Journal of Econometrics, 87, 115-143. https://doi.org/10.1016/S0304-4076(98)00009-8

Cabral, L. (1995). Sunk cost, firm size and firm growth. Journal of Industrial Economics, 43, 161-172. https://doi.org/10.2307/2950479

Cao, C. (2003). Growth Pains or Premature Senility: Zhongguancun and China's high-Tech Parks in Transition. East Asian Institute, national University of Singapore.

China Statistic Yearbook on High Technology Industry, various years. Zhongguo Gaojishuchanye Nian jian. Zhongguo Tongji Chubanshe, Beijing.

Ciccone, A. (2002). Agglomeration effects in Europe. European Economic Review, 46, 213-227. https://doi.org/10.1016/S0014-2921(00)00099-4

Ciccone, A., \& Hall, R. E. (1996). Productivity and the density of economic activity. The American Economic Review, 86(1), 54-70.

Colombo, M. G., \& Delmastro, M. (2002). How effective are technology incubators? Evidence from Italy, Research Policy, 31, 1103-1122. https://doi.org/10.1016/S0048-7333(01)00178-0

Combes, P., Duranton, G., \& Gobillon, L. (2011). The identification of agglomeration economies. Journal of Economic 
Geography, 11(2), 253-266. https://doi.org/10.1093/jeg/lbq038

Cull, R., Xu, L. C., \& Zhu, T. (2009). Formal finance and trade credit during China's transition. Journal of Financial Intermediation, 18(2), 173-192. https://doi.org/10.1016/j.jfi.2008.08.004

Du, J., Lu, Y., \& Tao, Z. (2012). Bank loans vs. trade credit: Evidence from China. Economics of Transition, 20(3), 457-480. https://doi.org/10.1111/j.1468-0351.2012.00439.x

Fazzari, S. M., Hubbard, R. G., \& Petersen, B. C. (1988). Financing constraints and corporate investment. Brookings Papers on Economic Activity, 1, 141-195. https://doi.org/10.2307/2534426

Fisman, R., \& Love, I. (2003). Trade credit, financial intermediary development, and industry growth. The Journal of Finance, 58(1), 353-374. https://doi.org/10.1111/1540-6261.00527

Ge, Y., \& Qiu, J. (2007). Financial development, bank discrimination and trade credit. Journal of Banking \& Finance 31(2), 513-530. https://doi.org/10.1016/j.jbankfin.2006.07.009

Glaeser, E. L., \& Gottlieb, J. D. (2009). The wealth of cities: agglomeration economies and spatial equilibrium in the United States. Journal of Economic Literature, 47, 983-1028. https://doi.org/10.1257/jel.47.4.983

Hall, B. H. (2002). The financing of research and development. Oxford review of economic policy, 18(1), 35-51. https://doi.org/10.1093/oxrep/18.1.35

Hu, A. G. (2007). Technology parks and regional economic growth in China. Research Policy, 36, 76-87. https://doi.org/10.1016/j.respol.2006.08.003

Hu, C., Xu, Z., \& Yashiro, N. (2015). Agglomeration and productivity in China: Firm level evidence. China Economic Review, 33, 50-66. https://doi.org/10.1016/j.chieco.2015.01.001

Hur, J., Raj, M., \& Riyanto, Y. (2006). Finance and trade: a cross-country empirical analysis on the impact of financial development and asset tangibility on international trade. World Development, 34(10), 1728-1741. https://doi.org/10.1016/j.worlddev.2006.02.003

Ito, B., Xu, Z., \& Yashiro, N. (2013). Does agglomeration promote the internationalization of Chinese Firms? RIETI Discussion Paper Series, 13-E-081, 1-31.

King, R. G., \& Levine, R. (1993). Finance, entrepreneurship and growth. Journal of Monetary economics, 32(3), 513-542. https://doi.org/10.1016/0304-3932(93)90028-E

Krugman, P. (1991). Geography and Trade, MIT Press, Cambridge, MA.

Lin, H. L., Li, H. Y., \& Yang, C. H. (2011). Agglomeration and productivity: Firm-level evidence from China's textile industry, China Economic Review, 22(3), 313-329. https://doi.org/10.1016/j.chieco.2011.03.003

Lin, Y. F., \& Xi, F. S. (2005). Xinxi, feizhenggui jigou fanzhan yu zhongxiao qiye rongzi (Small and medium financial institutions and small and medium enterprises financing). Jingji yanjiu (Economic study), 7, 35-44(July).

Long, C., \& Zhang, X. (2011). Cluster-based industrialization in China: Financing and performance. Journal of International Economics, 84, 112-123. https://doi.org/10.1016/j.jinteco.2011.03.002

Majumdar, S. K. (1997). The impact of size and age on firm-level performance: Some evidence from Indi. Review of Industrial Organization, 12, 231-241. https://doi.org/10.1023/A:1007766324749

Marshall, Al. (1920). Principles of Economics, London: Macmillan.

Nam, V. H., Sonobe, T., \& Otsuka, K. (2009). An inquiry into the development process of village industries: the case of a knitwear cluster in northern Vietnam. Journal of Development Studies, 46(2), 312-330. https://doi.org/10.1080/00220380902952373

Nickell, S., \& Nicolitsas, D. (1999). How does financial pressure affects firms? European Economic Review, 43(8), 1435-1456. https://doi.org/10.1016/S0014-2921(98)00049-X

Note 1. Data source: China Statistic Yearbook on High Technology Industry, 2009-2012

Note 2. Data source: China Statistic Yearbook on High Technology Industry, 2009-2012

Note 3. According to the definition of high and new technology industry by the Ministry of Science and Technology and the National Bureau of Statistics, the range of high and new technology industry includes manufacture of medical equipment, measuring instruments, medicines, aircraft and spacecraft, and communication equipment.

Note 4. Calculated based on the list of China's high and new industrial development zones.

Note 5. GMM: generalized method of moments 
Note 6. sales growth rate $=\left(\right.$ sales $_{t}-$ sales $\left._{\mathrm{t}-1}\right) / \mathrm{sales}_{\mathrm{t}-1}$

Note 7. $\ln$ (value added): logarithm of enterprise value added

Note 8. According to "Classification principle for firm size in China (2011)", industrial enterprises are divided into four categories: large, medium, small, and micro sized enterprise. Large industrial enterprise is defined as annual main business revenue $>400$ million yuan and $>1000$ employees. Medium industrial enterprise is defined as annual main business revenue $20-400$ million yuan and 300-1000 employees. Small industrial enterprise is defined as annual main business revenue 3-20 million yuan and 20-300 employees. Micro industrial enterprise is defined as annual main business revenue $<3$ million yuan and $<20$ employees.

Note 9. The fixed effects Tobit model cannot be employed here, since it is not possible to estimate the coefficients of time-invariant independent variables because $\alpha_{4}, \alpha_{12}, \mu_{\mathrm{i}}, \mu_{\mathrm{j}}$, and $\mu_{\mathrm{c}}$ in (2) and (4) capture the effect of time invariant variables (G.S. Maddala, 1987).

Palangkaraya, A., Stierwald, A., \& Yong, J. (2009). Is firm productivity related to size and age? The case of large Australian firms. Journal of Industry, Competition and Trade, 9, 167-195. https://doi.org/10.1007/s10842-007-0028-4

Piore, M. J., \& Sabel, C. F. (1984). The second industrial divide: possibilities for prosperity, Basic Books, New York.

Porter, E. M. (1990). The Competitive Advantage of Nations, Free Press, New York. https://doi.org/10.1007/978-1-349-11336-1

Porter, E. M. (1998). Clusters and the new economics of competition. Harvard Business Review, 76(6), 77-90.

Porter, E. M. (2000). Location, competition, and economic development: local clusters in a global economy. Economic Development Quarterly, 14(1), 15-34. https://doi.org/10.1177/089124240001400105

Rajan, R., \& Zingales, L. (1998). Financial dependence and growth. American Economic Review, 88, 559-586.

Roodman, D. (2009). How to do xtabond2: An introduction to 'Difference' and 'System' GMM in Stata. Stata Journal 9(1), 86-136.

Ruan, J., \& Zhang, X. (2009). Finance and cluster-based industrial development in China. Economic Development and Cultural Change, 58, 143-164. https://doi.org/10.1086/605208

Schmitz, H., \& Nadvi, K. (1999). Clustering and industrialization. World Development, 27, 1503-1514. https://doi.org/10.1016/S0305-750X(99)00072-8

Singh, H., Motwani, J., \& Kumar, A. (2000). Areview and analysis of the state of the art research on productivity measurement. Industrial Management and Data Systems, 100, 234-241. https://doi.org/10.1108/02635570010335271

Sonobe, T., \& Otsuka, K. (2006). Cluster-based Industrial Development: An East Asia Model, New York: Palgrave Macmillan. https://doi.org/10.1057/9780230596061

Windmeijer, F. (2005). A finite sample correction for the variance of linear two-step GMM estimators. Journal of Econometrics, 126, 25-51. https://doi.org/10.1016/j.jeconom.2004.02.005

Wurgler, J. (2000). Financial markets and the allocation of capital. Journal of financial economics, 58(1), 187-214. https://doi.org/10.1016/S0304-405X(00)00070-2

Yano, G., \& Shiraishi, M. (2012). Efficiency of trade credit finance in China. Comparative Economic Studies, 54, 203-225. https://doi.org/10.1057/ces.2011.30

Zhang, H. (2015). How does agglomeration promote the product innovation of Chinese firms? China Economic Review, 35, 105-120. https://doi.org/10.1016/j.chieco.2015.06.003

Zhang, H., \& Sonobe, T. (2011). Development of science and technology parks in China,1988-2008, The Open-Access. Open-Assessment E-Journal, 5, (2011-6). https://doi.org/10.5018/economics-ejournal.ja.2011-6

\section{Copyrights}

Copyright for this article is retained by the author(s), with first publication rights granted to the journal.

This is an open-access article distributed under the terms and conditions of the Creative Commons Attribution license which permits unrestricted use, distribution, and reproduction in any medium, provided the original work is properly cited. 